NBER WORKING PAPER SERIES

\title{
ASSESSING THE BENEFITS TO DEVELOPING COUNTRIES OF LIBERALIZATION IN SERVICES TRADE
}

\author{
John Whalley \\ Working Paper 10181 \\ http://www.nber.org/papers/w10181 \\ NATIONAL BUREAU OF ECONOMIC RESEARCH \\ 1050 Massachusetts Avenue \\ Cambridge, MA 02138 \\ December 2003
}

This is a draft of a report prepared for the OECD Trade Directorate. I am grateful to Ken Heydon, and his colleagues at OECD for extensive comments and help with logistical and bibliographical support. The views expressed herein are those of the authors and not necessarily those of the National Bureau of Economic Research.

(C2003 by John Whalley. All rights reserved. Short sections of text, not to exceed two paragraphs, may be quoted without explicit permission provided that full credit, including $(\mathbb{C}$ notice, is given to the source. 
Assessing the Benefits to Developing Countries of Liberalization in Services Trade

John Whalley

NBER Working Paper No. 10181

December 2003

JEL No. F1

\section{ABSTRACT}

This paper discusses the potential impacts of services trade liberalization on developing countries and reviews existing quantitative studies. Its purpose is to distill themes from current literature rather than to advocate specific policy changes. The picture emerging is one of valiant attempts to quantify in the presence of formidable analytical and data problems yielding only a clouded image of likely impacts on trade, consumption, production, and welfare.

John Whalley

Department of Economics

University of Western Ontario

London, Ontario, N6A 5C2

Canada

and NBER

jwhalley@uwo.ca 


\section{Introduction}

\subsection{Background}

This paper assesses the present state of quantitative literature which seeks to evaluate the potential impacts which would follow from global services trade liberalization as it relates to developing countries. It is important to emphasize that what are frequently referred to as developing countries are themselves also a heterogeneous group of countries. They span rapidly growing economies in Asia, negative growth economies (in GDP/capita) in Africa, middle income and very poor countries, small and large, landlocked and ocean access; heavily regulated and recently liberalized. I prefer the term poorer countries, and use this interchangeably with the term developing countries in the text. Much of the literature at issue is relatively recent, and is scattered in working papers and other less accessible sources. Policy makers clearly need help in unraveling this at times confusing and fragmentary picture of what the research community has to offer to guide their deliberations. This paper aims to do this rather than to advocate particular policy positions on global services liberalization.

\subsection{Nature of Services}

The paper begins by characterizing services as a majority of activity for most OECD economies (as measured by employment, and by value added originating), and a smaller but still large portion of activity for poorer developing countries. It suggests that so-called "core" services can best be thought of (see Melvin 1989) as relating to intermediation through time (banking, insurance) or space (telecoms, transportation, retailing, wholesaling), with a wide range of diverse additional service items making up 
the balance of what most people refer to as services (tourism, consulting services, government services, utilities). This diverse range of activities is typically treated in quantitative studies as a single homogenous entity, frequently labeled as services for analytical convenience, when in fact its heterogeneity suggests a different treatment for each. This heterogeneity is, in my view, key to better understanding how services trade liberalization could affect poorer countries.

\subsection{Impacts of Liberalization on Poorer Countries}

There is a general presumption in the poorer countries that they will lose from global services trade liberalization since their domestic service industries are inefficient and non-competitive. This view is despite the arguments from economists as to the gains to domestic consumers from lower prices and the joint benefits which accrue to both exporting and importing countries from exploiting comparative advantage and improved market access opportunities abroad. It is also despite the commonly held view that the production of many services are labour intensive, which economists believe should be the source of comparative advantage for poorer developing countries in services provision. There unfortunately appear to be few if no studies of the relative inefficiency of local versus foreign service providers in developing country service markets which allow the strength of these arguments to be evaluated on empirical grounds.

This caution towards global services trade liberalization in the developing world seems to reflect two concerns. One is the general assumption in the developing world that any future negotiated global liberalization of services trade will be largely one sided in the results it will yield. Their belief is that if new WTO multilateral (or even regional) 
services liberalization is negotiated, developed country service providers will likely gain significantly improved access to developing country service markets, but the converse (significantly improved access for developing country service providers to developed country service markets) will likely not happen. Asymmetry in negotiating power is one reason cited for this possible outcome. The presumption is that the present regulatory structure for most service market segments will remain in place in OECD countries, and few significant improvements in access to developed country markets for developing country service providers will occur. This outcome, for instance, is reflected in recent US bilateral agreements, including the US-Chile agreement.

In reality, through the process of ongoing regulatory reform in the OECD, changes are in fact being made in market access arrangements for developing country service providers, though these are not necessarily reflected in scheduled commitments in GATS in the WTO. Another important and neglected dimension to this conclusion is South-South trade, and the potential that developing countries have much to gain from liberalization of markets in other developing countries. The point is that in terms of model based (or quantitative) evaluations of the impacts of services trade liberalization, were genuine two sided liberalization to take place with their low wage rates developing country providers could well benefit. This is especially so if there are scale economies in service provision (as in banking, for instance). Most of the available studies of what benefits might flow from services liberalization assume there will be full multilateral opening of service markets, and results of studies must be interpreted in light of this presumption. If one-sided liberalization is the expected outcome, developing countries 
may well remain opposed to liberalization on the grounds it is non-reciprocal despite the results of studies.

The second caution that developing countries express is the nature and size of the adjustments in domestic economies which services liberalization may imply. One dimension of adjustment relates to potential foreign majority ownership and control of provision in key service sectors, and the related security and cultural concerns. Foreign entities having access to and control over bank records and financial information of domestic residents, for instance, is seen in some countries as unacceptable. Also, a vibrant and vital domestic broadcast or film industry may be viewed as integral to national cultural identity. Added to such concerns is the potential size of labour market adjustments if domestic banks are displaced by foreign banks, domestic by foreign airlines, and other large changes in the organization of labour intensive sectors which might follow after liberalization.

\subsection{Issues Addressed in the Paper}

Against this background, the paper identifies three central issues which existing literature on the quantification of the potential benefits to developing countries of services trade liberalization raises. For simplicity in the discussion of studies I assume, as in the literature, that this is in fact multilateral liberalization rather than the unilateral liberalization developing countries presume it may well be in reality.

The first is the representation of and measurement of barriers to services trade in individual countries, and the associated issue of measuring the size of services trade itself. Both the level and composition of global services trade is poorly measured at 
present because there is no formal customs clearance for services trade. Despite this, the literature consensus is that services trade is large (the WTO put it at $30 \%$ of combined trade in goods and services), and growing (at perhaps double the rate of goods trade). Current information on barriers to flows of services trade reflects a number of sources. One measures the quantity impacts from various restrictions as estimated by economic models. Another uses estimates of price differentials for across domestic and foreign service providers across national markets. Yet another is frequency data showing how often regulatory measures are used in particular service segments in particular countries (see Hoekman (1995)). Tax equivalents are used in some of the literature to capture associated barriers to FDI flows which might otherwise accompany freer service trade flows (see Dee and Hanslow (2000)).

In the paper I suggest that these are major conceptual problems with all of these estimates of the size of barriers, while acknowledging that no other meaningful data exist which can be used and many problems inevitably arise with whatever approach is followed. By way of illustration, frequency data ${ }^{1}$ do not allow users to differentiate between those barriers which restrict trade (i.e. are binding constraints on trade), and those which do not restrict trade because they are redundant (i.e. are non binding constraints). Neither do studies substantively enumerate and represent the various ways in which restrictions on services trade apply and how these affect the assessment of impact, nor do they assess the relative severity of barriers. To an economist working on the impacts of distortions of trade, available barrier estimates from frequency data in no way provide meaningful estimates of marginal barriers to trade. Another example is that

\footnotetext{
${ }^{1}$ The UNCTAD MAST (Measures Affecting Services Trade) dataset is one of the more recent and comprehensive of these frequency data sets.
} 
if data on costs of service provision in different markets are obtained, any differences across markets may merely reflect differences in domestic regulatory environments and not barriers to entry for foreign service providers. Price differences across countries for services can also reflect quality differentials across countries rather than barriers. Using model results to infer barriers to trade can yield outcomes that quantity impacts from barriers may be negative from model residuals even where it is clear that binding restraints on trade apply.

A second issue discussed is the interpretation of results from existing model based literature seeking to quantify the impacts of trade liberalization in services (see Robinson et al (1999), Dee and Hanslow (2000) and Brown, Deardorff and Stern (2002)). Most of what is available involves numerical simulation exercises using (typically global) general equilibrium models based on conventional models of trade liberalization in goods (see Whalley (1985)). In these exercises, producer services are typically identified as an input into intermediate production and barriers to service trade are represented in the form of advalorem tariff like restrictions. These can be in tax equivalent (for FDI flows) or tariff equivalent (for service flows) form. The size of initial barriers, how they change under liberalization, elasticities, and the size of service trade flows, along with relative country size and any differences in market structure then determines results much as in conventional goods models of trade.

Several problems are encountered in interpreting the results from available studies. One is that even taken on their own merits results appear to be confusingly contradictory, and especially so for individual developing countries. For example, Dee and Hanslow (2000) produce results showing extremely large gains from services 
liberalization in the Uruguay Round for certain developing countries (a 14.6\% of GDP gain for China, and 5.1\% gain for Indonesia). They also suggest globally, that over one half the total gains from goods and services liberalization accrue from services liberalization. In contrast, Robinson et al (1999) using similar GTAP data put the gains to China at $0.34 \%$ of GDP, ASEAN and $1.29 \%$, and South Asia at $1.13 \%$. Another example is that Verikios and Zhang (2000) suggest losses to Malaysia from telecom liberalization, and losses to Indonesia from financial services liberalization using the same data as Dee and Hanslow. They show only small gains for China. There are important differences in approach between these studies. Dee and Hanslow explicitly incorporate GATS mode 3 restrictions while Robinson et al. use a modeling approach which does not differentiate between cross country factor flows and provision of goods and services. Also, different estimates of barriers are incorporated in the two models. Brown, Deardorff and Stern suggest global gains from Doha Round liberalization of \$574 billion per year with the large majority ( $\$ 413$ billion) arising from services, and the largest absolute gains going to developed countries. Fully explaining all the differences in the magnitude of the results is difficult, and reconciling disparities in results is difficult when seemingly similar data sources are involved.

Another problem is that there is analytical literature which purports to show that when intermediation services are explicitly represented in their true economic form, rather then being represented in advalorem equivalent form, the two fundamental theorems of welfare economies need not hold. Because of this property, welfare impacts from liberalization in services trade (even in small open economies) can be negative rather than positive as generally presumed in the goods like models used in the literature. 
Ryan (1990) was an early piece to point this out. Chia and Whalley (1997) provide an example of welfare worsening liberalization in the case of trade liberalization in banking services. Bhatterai and Whalley (1998) show how explicitly modelling telecoms liberalization in a network structure can change perceptions as to the division of the gains from liberalization between small and large countries. The implication seems to be that only limited confidence can be attached to results obtained from the advalorem equivalent modelling used in numerical literature because the analytical structures used rule out alterative results. This problem would arise even were the results of individual studies not contradictory one with another.

\subsection{Key Features of Model Results}

Despite these problems, even though they are contradictory across countries, a central broad feature of results taken as a whole is that in models where services are treated as akin to goods and there is no factor mobility, effects are positive but small for most countries. However, where FDI flows enter (effectively capturing capital flows) effects are much larger and more variable across countries. This suggests that it may be the case that as surrogate liberalization of global factor markets, services liberalization can have big effects and this could be the best way to view it in assessing the potential impacts on poorer developing countries. Both some earlier and recent models capture FDI effects (effectively GATS Mode 3 commercial presence and ownership restrictions) and more recent work captures labour mobility effects (GATS Mode 4 restrictions on mobility of service providers). Existing literature estimates suggest very large global gains from the removal of immigration restrictions to cross border flows of labour 
services, and seem to point to a conclusion that this could be the biggest part of the services liberalization nexus for developing countries. It perhaps suggests that developing countries should push for immigration and worker mobility restrictions to be included in GATS negotiations in the WTO, even though developed countries are cautious about doing so.

The paper also discusses recent econometric literature linking growth performance to services trade liberalization (see Francois and Schuknecht (1999) and Mattoo, Rathindran, and Subramanian (2001)). Importantly, Mattoo et al, claim that growth rates of up to 1.5 percentage points higher occur for economies that liberalize their telecoms and financial services sectors: Francois and Schuknecht also claim strong growth effects follow empirically from services liberalizations. While seemingly powerful in their policy thrust, there are problems once again in interpreting the results. One is that excluded variables can be the larger source of higher growth. For example, higher growth rates may largely reflect higher savings and investment rates, which generate more intermediation and hence more service use. So it could be that the higher investment rates drive higher growth rates more so than larger use of services following upon liberalization. This work is also generally a theoretical and does not differentiate between once and for all level effects from liberalization and permanent growth effects. It also needs to be borne in mind that endogenous growth literature also provides arguments as to why protection can be welfare improving if there are uninternalized externalities (as in so-called A-K models) (see Young (1996)) and these may also apply to services as well as to goods. 
The bottom line conclusions offered are that while services liberalization is indeed an important issue for developing countries, the dominant issues for them are likely to be how much access improvement will they experience in service markets abroad (both in OECD and other developing country markets), and what will be the impacts for them if there are changes in labour mobility restrictions. For now studies which address these issues remain informed by poor data, major conceptual difficulties, and in the modelling area are characterized by contradictory results. On the other hand the limited econometric studies available point to strong growth effects. The outcome is that their contribution to policy debate in the area may seem unclear and confusing to outsiders but this often is the state of academic research as it relates to current policy debates. The key themes of potentially viewing services trade liberalization as surrogate liberalization of factor (capital and labour flows), and focusing on mode 3 and (especially) mode 4 GATS liberalization might be the most important insights for policy makers to draw. 


\section{General Considerations in Evaluating the Impacts of Services $\underline{\text { Trade Liberalization on Developing Countries }}$}

Prior to reviewing existing literature relevant to the developing country interest in global services trade liberalization, it may be helpful to first highlight a number of wider conceptual issues relevant to the discussion.

\subsection{The Developing Country Interest in Trade Liberalization in General}

The presumption behind most discussion of potential developing country interests in services trade liberalization is that countries gain from more open services trade in ways which are similar to trade liberalization in goods. This reflects the idea that countries have differing comparative advantage in the production of both goods and services, and more open trade will allow comparative advantage to be more fully exploited in all countries. Put simply, the thinking is that propositions regarding the gains from freer trade apply equally to both goods and services. There are, however, many complications with this line of argument even though it is instinctively where most academic economists finish up in their thinking.

First, accepting for now the proposition that trade in services and goods can be treated as analytically similar in this way, the issue of how developing countries benefit from services trade liberalization is subject to all of the nuances set out in the literature on trade policy. While most academic economists instinctively believe that there are benefits for all countries from freer trade, over the years they have nevertheless devoted a considerable portion of their intellectual energy to producing arguments as to why the contrary may be true. These include arguments for an optimal tariff (terms of trade 
improvement from protection), for infant industry protection, for tariffs which transfer rents (rent shifting), and tariffs that offset other domestic distortions. These arguments presumably apply equally to trade in services and goods if they are analytically similar, and hence qualify the presumption that freer global trade in service is a good thing.

Second, there are a series of arguments about protection of trade in goods that relate in one way or another primarily to developing countries and these presumably also come into play in discussing trade in services. Examples are that increased trade can be immiserizing due to a terms of trade deterioration; in a Lewis model with traditional practices in agricultural sectors (average rather than marginal product pricing of labour) protection of traded goods sectors is called for to pull labour into import competing modern sectors; in a Harris Todaro model with an urban sector specific downward rigid real wage and unemployment, an import subsidy can be beneficial.

In addition there are many broader issues identified in the literature about the form global trade liberalization takes and hence its impacts on developing countries, and these would again apply equally to services and goods. If, as is usually argued, countries gain more from improved access to larger foreign markets (given the larger size of OECD markets) than from their own liberalization, what they should seek is genuinely multilateral liberalization rather than only participate in unilateral liberalization. This should include freer South-South trade in services, as well as OECD/non OECD trade. Being smaller economically, developing countries have less bargaining power than larger developed countries in trade negotiations, and this applies equally to trade in goods and services and hence globally negotiated outcomes may well be asymmetric. 
Developing countries also often argue that both trade liberalization and its impacts need to be evaluated in the context of its wider impacts on the developmental process, including implications for growth and poverty, which are not typically centrally discussed in conventional trade literature. These arguments also presumably apply equally to trade in goods and services.

Hence while the presumption is that global liberalization of trade in services will yield gains for both developed and poorer developing countries, and hence the central issue is to evaluate the size of any resulting gains, it needs to be borne in mind that the arguments even from conventional literature on trade in goods are more nuanced than this.

\subsection{Differences between trade in services and trade in goods}

Accepting for now that there is a general presumption that global trade liberalization in either goods and services is broadly beneficial for developing countries (a contention some would challenge), the next issue is whether goods and services differ in some important way. Do they need to be approached differently in evaluating the quantitative impacts involved?

This is a key issue in discussing the impacts of services liberalization on poorer developing countries, since much if not most of the existing quantitative literature treats services as analytically similar to goods. The approach is to define a single product, commonly called producer services, which is an input into production and against which trade protection operates with a tariff like instrument. Liberalization is then a reduction in or elimination of the tariff. Not surprisingly numerical results from models are similar 
to those of trade liberalization in goods. Small positive gains accrue to most countries if there are no factor mobility effects captured, as in goods liberalization models.

In reality, however, the term services captures a heterogeneous group of activities spanning banking, insurance, transportation, telecoms, consulting services, retail and wholesale trade, and several others. Much of this activity facilitates transactions, providing the economic function of intermediation either through time or space which, as pointed out by Melvin (1989), when explicitly modelled as such can produce different implications for trade liberalization.

Ryan $(1990,1992)$, for instance, shows that when banking is explicitly modelled as intermediation services that themselves do not directly provide utility, but instead facilitate intermediation between borrowers and lenders, liberalization of trade in banking services can reduce GDP, and even welfare. Chia and Whalley (1997) have produced a numerical example of welfare worsening trade liberalization in banking services based on this approach. The results from such examples reflect the use of specific formulations and parameter values and functional forms and are hence not general results. They do, however, suggest a weakening in the general presumption that gains will be automatically shared between developed and poorer developing countries if global liberalization of services trade occurs. Bhatterai and Whalley (1999) provide a related analysis of the implications of liberalization in network services (effectively telecoms) where the same theme emerges that recognition of the special features of individual services changes the analysis of the impacts of services liberalization.

Another difference is that to achieve meaningful trade liberalization in services may require modifications of factor mobility restrictions which may not be needed for 
goods liberalization. This is recognized in Modes 3 and 4 of GATS which effectively relate to capital (FDI) mobility and labour (service provider) mobility. With restricted or segmented global factor markets (and especially labour markets), large effects can come from services liberalization if such liberalization becomes an indirect mechanism for liberalizing global factor markets. This is a central issue for the poorer developing countries who have long pushed for liberalization of immigration controls in OECD countries, since global services liberalization may be a vehicle for them to achieve this end.

Thus whether services are treated as being different from goods, whether their economic characteristics are explicitly modelled, and how factor flows are treated can all make a large difference to the perceived effects of trade liberalization in services (and both to sign and magnitude).

\subsection{Types of services trade liberalization; deregulation/competition/barrier $\underline{\text { reduction }}$}

A further key issue in discussing trade/liberalization in services and its impacts on poorer developing countries is that the types and forms of liberalization need to be fully and carefully specified. As a result, these often have to be discussed in ways which do not arise with liberalization in goods trade. Barriers to the flow of goods typically arise as customs and other physical restraints on trade are administered at national borders. Thus, for goods trade, most discussion of liberalization focuses on tariffs (and less so) on other instruments. 
Within the services trade community and in the policy literature in general, there is an understanding that the outcomes of services liberalization will depend heavily on the regulatory environment and the need for liberalization to be underpinned by a sound regulatory framework. Restraints on trade no longer apply in the same way as for goods at borders; a wider variety of restraints than those typically applicable to goods apply beyond borders and hence within national markets. Also, since services generally have no tangible form and hence cannot be physically restrained at the border, but typically foreign service providers need to have to have entry to the national market either for the service itself. The entity that provides the service, or service providers themselves may be restricted in terms of their mobility, and it is here that restraints on services trade effectively operate.

Barriers to service provision may operate through entry barriers to local markets (rights to establish, or to provide services), rules on conduct (regulation), on the number and size of competitors in a market (competition rules), and in other ways. As a result many more barriers come into play with services than with goods trade. They are more complex, and their effects more numerous. Market structure, conduct, and performance are all key and all need to be evaluated when discussing quantitative impacts of global liberalization of services trade on poorer developing countries.

\subsection{How different are barriers across developed and developing countries?}

The actual numbers for barriers to service trade flows used in different studies for barriers to service trade flows are discussed in more detail below, but it is worth pointing out at this stage that the general perception is both that services trade is considerably 
more heavily restricted than goods trade (and in manufactures in particular, rather than in agriculture where high barriers still apply), and considerably more so in the poorer developing countries than in developed countries. As noted in the introduction, developing countries in reality are an extremely heterogeneous group of countries with sharply differing characteristics and use of restrictions on service provision, but for now we will use this terminology in discussing barrier differences across broad country types.

The precise extent of market segmentation across countries in services is not well documented, but is often claimed to be large. For example, despite claims of ever growing globalization, in most countries around the world branch banking is still provided by local banks, insurance policies are still written by local companies, internal air transportation is by local carriers, as is road, rail, and maritime. Retailing continues to be dominated by domestic retailers in most country markets.

Among developed countries, there seems to be evidence of growing cross country service trade. Some of this reflects cross country foreign direct investment, or buyouts/mergers of local service providers by foreign entities. Thus, growing market integration in the services areas seems to be occurring in these countries, even though domestic regulations often seem slow to change. In the developing countries in contrast, less market integration and cross market penetration in services seems to have occurred although the process would be poised to accelerate more rapidly than in the developed world. For now, local service providers remain as locally owned entities, and interdeveloping country service trade is small in part because of barriers to foreign service providers. Service trade as a share of total trade is also correspondingly smaller in developed than in developing countries. 
The presumption in any quantification of impacts of global liberalization of services trade on poorer developing countries is that barriers to service trade are currently large in both developed and developing countries, and while relaxing a little, probably are more restrictive on average in developing than in developed country markets. This presumption underlies arguments from the policy community for large potential effects to follow from services trade liberalization as it relates to South-South trade. 


\section{The Representation and Measurement of Barriers to Services $\underline{\text { Trade }}$}

As noted earlier, both characterizing and measuring the size of barriers to the international flow of services is considerably more complex and nuanced than is true for barriers faced by international trade in goods and the problems encountered in this area also affect any discussion of the quantitative impacts of services trade liberalization on developing countries.

Thinking on barriers facing international trade in goods in part reflects the structure of the 1967 General Agreement on Tariffs and Trade incorporated into the Charter of the WTO as GATT 1994. The GATT structure tries to limit barriers to goods flows to transparent and bound tariffs which can then be negotiated down to progressively lower levels.

The principle of National Treatment (no discrimination against foreign goods within national economies) in the WTO Charter implies that all barriers apply only at the border as goods enter national markets. This is typically through a tariff or quota, although quotas are formally banned under Article 11 of GATT 1994 in the WTO charter. For services the structure under the 1994 GATT is different. No national borders apply for services trade since there is no customs clearance. Barriers to the free international flow of services take many other forms in place of tariffs; regulation, entry barriers, restrictions on the mobility of service providers. The structure of the GATS thus differs from the GATT; for instance, National Treatment does not stand as an automatic right and must be bargained for. This all makes discussion of and classification of barriers to service flows more difficult than for goods, since trade economists are usually 
drawn back to analogies with restrictions on goods flows, and look for tariff like measures of barriers. Many of analogies can be misleading and even ultimately uniformative.

\subsection{Approaches to Classifying and Measuring Barriers to Services Trade}

There are basically two different approaches used in the literature to classify barriers to trade in service items for the purposes of both measurement of their size and wider liberalization discussion. One is to separately examine the structure of regulation, entry barriers, and mobility restrictions for in each service market. Different restrictions/regulations apply, say, in banking from, say, road transport because of the differences in the characteristics of the service. Under this approach, a restriction on the value of reserves of a foreign bank to be retained within a country is a different restriction to one which requires, say, that trucks at the border must enter with a full tank. If they are converted into any comparable form in terms of economic impact, this can be attempted by examining their cost implications. However, some restrictions imply a fixed cost for entering a market, others change marginal costs, others effectively set upper bounds on the quantity of service provided, or establish minimum quality standards. Comparing barriers and evaluating their impacts is thus inherently difficult, and the heterogeneity among broad service types (banking, transportation, for instance) is a further complication, as is the heterogeneity within categories (types of services offered by financial institutions).

The other approach is that which has been taken in most of the numerical modelling literature on trade in services and is to treat all services as a single 
homogeneous entity. Unfortunately, this forced and artificial generality can yield misleading results if used as the basis for policy debate on global services trade liberalization and its impacts on developing countries. In some more recent literature there are partial modifications to the approach, such as attempts to differentiate among the various ways that services can be supplied. The typical treatment is to model FDI flows as linked to services provision (along the lines of GATS Mode 3 (commercial presence)). Labour mobility arrangements under GATS Mode 4 (temporary movement of service providers) has also been separately modelled. But classifying functional barriers which may be service category specific as part of a general categorization by mode of supply remains as the central feature of the approach.

\subsection{The GATS Modes of Supply}

Because of the key role played by negotiation in the WTO in the services area, the approach to services taken in General Agreement of Trade in Services (GATS) becomes relevant to both the discussion of and quantification of the impacts of services trade liberalization. This is because it provides the broad framework within which the policy community (as distinct from the research community) discuss trade liberalization in services. Until relatively recently the different modes of supply for services have made relatively little difference to how economic modelers view services, and this has been one of the central weaknesses of their work. Markusen, Rutherford, and Tarr (2000) represent one recent attempt to deal with Mode 3 restrictions; Winters (2002) discusses the modelling of Mode 4 restrictions. These are discussed below. 
The GATS classifies services into 155 service types, and differentiates between four modes of supply. The modes provide a devise to facilitating the making of commitments in negotiation. These modes are:

Mode 1: $\quad$ Cross border supply. This is where a service is supplied directly to a consumer's country of residence from a supplier's country of residence (eg. legal advice from abroad given by letter or telephone).

Mode 2: $\quad$ Consumption abroad. This is where a service is supplied to a consumer by the consumer physically moving to the suppliers country of residence to receive the service (eg, a visit to a law office abroad).

Mode 3: $\quad$ Commercial presence. This is where supply of a service by a commercial organization involves moving to a consumer's country of residence (FDI, for instance).

Mode 4: $\quad$ Presence of Natural Persons. This is where a service is supplied by the (typically temporary) movement of a services provider to the consumer's country of residence (eg. labour mobility of the service provider).

Thus under this approach barriers to trade in services are effectively categorized both by the type of service to which they apply and by mode of supply. The idea is that in negotiation countries will schedule commitments on barriers to service trade using this categorization. Thus, by way of example, a country which commits to always allow five star hotels to operate within their territory schedules a commitment under a type of service (tourism) and a mode of supply (commercial presence). The aim is to have negotiations occur through which countries can jointly agree to schedule commitments under the structure of the GATS. This involves a different procedure from the bilateral 
exchange of concessions on goods trade (extended via MFN) as practised in the old GATT.

For the purposes of the discussion here, the key point is that while the GATS, in effect, provides a vehicle for classifying and cataloging restrictions to the free international flow of services; it does not provide an analytical framework for evaluation of their impacts. It is description and classification, not analysis.

\subsection{Analytical Issues with the Treatment of Services When Representing Trade $\underline{\text { Barriers }}$}

To evaluate the impacts of service trade restrictions on developing (or other) countries, some method of grouping restrictions on service trade captured by the GATS classification scheme must be used which allows their impacts to be assessed within a meaningful analytical structure. One way to proceed is to assume that all service trade restrictions have effects equivalent to those of a tariff as they apply to the flow of services across borders even though no customs clearance applies and tariffs do not formally apply to services. This is the treatment adopted in most quantitative literature (see below) which uses advalorem equivalent treatment of barriers to services trade.

In analytical literature, however, barriers to free international flows of services are considerably more multifaceted than this, and so alternative formalizations and conceptualizations of the barriers at issue are involved. Many are regulatory in nature, and perhaps fit more comfortably within the large literature on industrial organization more so than within conventional trade literature. 
Thus, by way of example, there may be barriers to entry to domestic markets for foreign service providers. These barriers may be classified under mode 3 of GATS but may include not only rights to establish, but also sector specific rules on entry and conduct. Examples would be the scheduling of domestic banks in banking legislation; domestic asset rules for insurance policy writers and other such arrangements. Each of these rule regimes is typically sector specific and operates in different ways.

There may also be regulations which relate to performance requirements for participants in domestic markets. These may not necessarily discriminate against foreign firms, but if domestic practices differ from those used abroad and there are scale economies the effect can again be to retard trade. Further barriers may arise with limits on the mobility of service providers (both forms and persons), perhaps requiring use of local rather than foreign forms and or local labour in service provision. Ownership barriers, such as in airlines and (in some cases) telecoms and insurance are one example of such barriers. Immigration and visa arrangements yielding GATS mode 4 supply restrictions are another. The latter play a large and central role as far as the impacts of service trade flow restrictions on developing countries are concerned.

Analytically, all these different barrier treatments will yield different predictions as to the effects on trade in service flows relative to modelling which uses ad valorem equivalent tariff forms. Relatively little is known numerically as to the differences in the orders of magnitude involved, and/or the signs of the effects from explicit barrier representation compared to ad valorem treatment. In the goods area (especially in agriculture) it is thought the differences between advalorem equivalent form and explicit representation can be major. 


\subsection{Ad Valorem Treatments of Barriers, Frequency Indices, Price Based and Quantity Based Measures $^{2}$}

As noted above, the approach followed in most of the numerical modelling literature on services is to treat barriers to services trade in advalorem form, as either tariff or non tariff equivalent instruments. A widely used approach to gauge their quantitative impact is to construct frequency measures showing the extent of usage of service trade restrictions, from which the severity of the impacts of such measures on trade flows are loosely inferred. To be fair to this work, no major claims are made that these measures tell one very much about the true quantitative impact of restrictions on trade flows. They appear to be both constructed and used as few alternatives seem available and there is an understandable demand for some form of quantitative assessment.

The key paper here, is by Hoekman (1995) who uses the GATS commitment of schedules of member countries to make a series of calculations. He utilizes all 155 service categories in GATS and the four modes of supply for each importing country and gives values of $1,0.5$, or 0 to each category/mode possibility for each country depending upon frequency of use of measures. If no restrictions apply for a given mode of supply in a given sector a value of 0 is assigned. If restrictions operate for a given mode of supply in a given sector a value of 0.5 is assigned. These scores are labeled openness/binding factors. He then aggregates the resulting assigned values across modes and across service categories.

\footnotetext{
${ }^{2}$ This section draws on the discussion of the literature attempting to use these various approaches these measures set out in Copeland (2002).
} 
Hoekman uses these assigned scores to calculate three ratios for each sector. The first sums indices and divides them by $620(155 \times 4)$ for each country. The second calculates the sectors/modes listed with restrictions as a share of the maximum possible, weighted by the openness/binding factors. The third calculates the share of no restriction entries in either a member country's total commitments or relative to the universe of 155 possible sectors.

A number of subsequent authors (particularly those associated with extensive work undertaken by the Australian Productivity Commission) have extended this approach and constructed more elaborate frequency measures which they label as trade restrictiveness indices. The basic approach, however, remains the same and most of the difficulties of interpretation which the Hoekman frequency measures encounter remain. Since Hoekman's paper these measures have been calculated in a series of industry studies; for telecoms by Warren (2001a and 2001b); for banking by McGuire and Schnele (2001a); for maritime transport by McGuire et al (2001b); for education by Kemp (2001); for distribution by Kalirajan (2000) and for professional services by Nguyen-Hong (2000). Hardin and Holmes (1997) also use frequency indices to evaluate barriers to FDI across service industries. The edited volume by Findlay and Warren (2001) contains an accessible and helpful compilation of some of this work.

In calculating these extended frequency indices, information on actual restrictions on trade and investment in specific service industries is typically drawn on from a wider range of sources than just the GATS schedules. Restrictions receive subjective scores and are then grouped into categories, and each given a numerical weighting. These typically reflect some form of subjective assessment of the costs of these restrictions in 
terms of economic inefficiency. Several indices are typically calculated for each industry to yield measures for different notions of barriers to trade.

As an alternative to the frequency index approach to measuring barriers, price based measures of barriers to service trade have been proposed, but thus far little calculated. Ideally they should reflect differences between domestic and foreign prices for key service categories across supplying and using countries. Francois and Hoekman (1999) propose (but do not construct) a measure based on gross operating margins. They suggest these should be measured in ratio form as (total sales revenue minus total average costs)/total average costs. Alternatively, price based measures have been constructed using econometric methods to construct cross country cost measures by Trewin (2001) for telecoms, Kalirajan et al (2001) for banking, Kang (2001) for maritime transport, Kalirajan (2000) for food distribution, and Nguyen-Hong (2000) for engineering services.

Quantity based measures of the severity of service trade restrictions are typically based on results of econometric models. The idea is that these should in some way reflect the determinants of service trade and hence be able to predict what service trade flows would be if there were no restrictions in place. This work typically extends earlier work of this type used for goods trade to measure barriers to goods flows by residual. Francois and Hoekman (1999), for instance, fit a gravity model to bilateral trade flows in services between the United States and its trading partners. Differences between predicted and actual trade are then taken to imply the effects of barriers to trade. Warren (2001) uses an alternative econometric procedure to develop quantity based measures for barriers facing trade in telecommunications services. 


\subsection{Pitfalls in the Measurement of Service Trade Barriers}

These measures of barriers to service trade flows, while clearly defensible on the grounds that this is all there is, nonetheless encounters numerous pitfalls and must therefore be used with great care. This makes any quantitative discussion of impacts of services trade liberalization on developing countries using them difficult to interpret with confidence.

First there is the issue that with multiple restraints on trade it is not clear which restrictions are binding and which are not. While frequency data only evaluate whether restrictions apply for each of 620 GATS cells for a given service type and across all four modes of supply, it is not clear that all aggregated restrictions are, in fact, binding restraints on trade. Some may restrict trade, some may not. Some may compound one with another, others may offset each other. In the literature on economic distortions in general, such as tax policy, the extent to which curious legal instruments of intervention in practice compound or offset is a major theme of literature. None of this appears to be present in the literature on service trade restrictions.

Second, just because restrictions are present their quantitative significance need not be the same across restrictions. Their marginal effects on trade will typically differ. And yet in frequency measures they are aggregated as if they are all in some sense equiproportional in impact. There seems no logical reason why this need be the case.

Other problems can also arise. Frequency measures may mask country discrimination in the application of barriers, even though both de jure and de facto discrimination are considered breaches of national treatment under the GATS. Offsetting subsidy type and restrictive measures may apply and these offsets will need to be taken 
into account. Defacto application of regulation and dejure form can differ, just as applied and bound tariff rates differ for trade in goods.

As far as quantity based measures are concerned, measures are typically based on model generated residuals given by observations relative to econometric model predictions. Not only is there much debate as to which is the most appropriate model for such purposes, barrier estimates obtained in this way can be negative even when no trade restricting interventions apply. Also, quantity based measures can be positive even when frequency indices are zero.

Price based measures also have problems of interpretation. Not only is price data on service types extremely hard to obtain, at a conceptual level differences in domestic regulation can imply differences in costs of service provision in different markets and hence prices across countries even if there are no formal barriers. Thus price differences across countries for services need not be related to barriers, even if they could be measured. Moreover, the price changes generated by a barrier depends on demand and supply elasticities, and without elasticity estimates (which are not available) it is not possible to move easily between observed price differences and ad valorem barriers which models implicitly assume generated them.

Thus interpreting barrier measures for services trade faces many pitfalls. One can argue this is true in general for most observations of economic phenomena interpreted in some analytical model equivalent form, but at the end of the day the problems with barrier estimates for service trade seem especially severe. They seem to be used solely as the best alternative given the policy prerogative of providing some form of numerical assessment of impact of proposed policy change. Evaluated their reliability relative to 
any form of absolute standard is clearly difficult, but it would seem that for now they can only be described as wanting. 


\section{Quantifying the Impacts of Trade Liberalization in Services on Developing Countries}

Beyond measuring the size of service trade barriers, a number of studies also attempt to quantify the impacts which would follow if global liberalization involving lowering them were to occur. Some of the results from these models explicitly relate to poorer developing countries. These quantitative studies in the main involve the use of numerical general equilibrium models. They are used to make counterfactual equilibrium calculations in which barriers to service trade flows are allowed to change and base case data and simulated equilibria compared. This involves calibration to a base case data set and the use of various loosely specified and quasi literature based elasticities which are key to the counterfactual behaviour these models predict. The use of these models to analyze liberalization barriers to the full international flow of goods is reviewed in Shoven and Whalley (1984) and Reinert and Francois (1997).

\subsection{Model Features}

There are a range of model treatments used in the these models. Key papers are Robinson, Wang, and Martin (1999), Dee and Hanslow (2000), and Brown, Deardorff and Stern (2002). Typically, services are treated in these models very much like goods with producer services modeled as an intermediate good, and some models also allow trade to be generated by differences in factor endowments as well as by product differentiation as in more recent goods trade models. As in the modelling of goods trade, some models (such as Markusen, Rutherford, and Tarr (1999)) allow for multinational activity and endogenous choice by multinational forms of whether to export or set up a 
branch plant. Models typically do not explicitly represent the different modes of supply in the GATS, although FDI flows (close to mode 3) and labour mobility restrictions are captured in more recent models. Winters (2002), and Winters, Walmsley, Wang, and Grynberg (2002) explicitly discuss the modelling of mode 4 GATS restrictions to service flows. It is not a feature of these models that they employ explicit characterizations of individual service elements (banking, insurance, etc.) and these are typically not explicitly recognized.

\subsection{Overview of Model Results}

The results from these models typically show that multilateral liberalization of services trade will increase global income and welfare, but they also show that the distribution of the resulting gains is sensitive to the model specification used. This point is important in understanding what the model implications of global liberalization in services are for developing countries.

Overall, there tend to be global gains from liberalization of service flows and they tend to accrue to all countries, but the effects are sometimes relatively small. Reductions in barriers are typically much larger than occurs for goods, but the magnitudes of gain are of a similar order to those obtained from earlier simulations of the effects of freer goods trade. By way of example, Dee and Hanslow report results which they suggest show the world would be better off by $\$ 260$ billion if all post Uruguay Round barriers to trade in both goods (manufactures and agriculture) and services were eliminated. About $\$ 50$ billion of gains comes from agricultural liberalization, $\$ 80$ billion comes from manufactures liberalization, and around $\$ 130$ billion form services liberalization. Simply 
put global gains from remaining goods liberalization (including agriculture) and services liberalization are of a similar magnitude. The $\$ 260$ billion global gain compares to initial GATT estimates of $\$ 500$ billion/year form Uruguay Round liberalization (see Francois, McDonald, and Nordstrom (1994)), and later ranges of $\$ 90-\$ 300$ billion (see Whalley (2000)). The Uruguay Round estimates had no meaningful estimates of gains from services trade liberalization.

A possible explanation of the seeming paradox of equal size effects across goods and services in Dee and Hanslow's results is that larger barriers apply to a smaller fraction of trade in the service area, and so gains relative to GDP are similar for goods and services (accepting the analytical structure and parameter values used). An important characteristic of this set model results is that where as in Brown et al (1996), Chadha (2000), and Benjamin and Diao (2000) there is no endogeneity in foreign direct investment, gains tend to be positive throughout the world. ${ }^{3}$ Where, however, studies explicitly incorporate foreign direct investment flows results are considerably different (as in Markusen et al (2000)), suggesting that liberalization involving commercial presence (mode 3 in GATS) could well be an important factor in services trade liberalization.

Robinson et al (1999) report no welfare effects from services trade liberalization but instead focus on output and trade effects. They show small output effects in most regions (I $2 \%$ ) with perhaps surprisingly negatives in service industries and positives in manufacturing and agriculture. The largest positive effect is a $+8.3 \%$ output increase for trade and transportation in the Asian NICS; the largest negative is a $3.37 \%$ fall in output

\footnotetext{
${ }^{3}$ Copeland (2002) emphasizes this point, and the related point below concerning results from models that incorporate FDI flows.
} 
of public housing in ASEAN. They do, however, show very large export effects (over $50 \%$ increases in trade, transport, private and public services) in most countries. Their model also captures induced effects on total factor productivity growth.

Brown, Deardorff and Stern (2002) assume a 33\% reduction in all barriers to global trade in both goods and services to characterize an eventual outcome of the WTO Doha Round. They show a small welfare loss from liberalization in agriculture (seemingly due to the elimination of export subsidies), global welfare gains of $\$ 103$ billion from reductions in manufactures tariffs, and a much larger gain of $\$ 413$ billion from services liberalization. The largest absolute gains go to the developed countries.

\subsection{Interpreting Model Results}

Both interpreting model results and understanding why they occur is unfortunately often difficult and authors do not always provide clear explanations for all features of their analyses. The results in Dee and Hanslow produce a good example of the many pitfalls that can. They show that of the additional US $\$ 130$ billion of gains arising from services trade liberalization, about $\$ 100$ billion would accrue in China alone. Global services trade liberalization in their model results seemingly imply that effects involving access for foreigners to the Chinese market will dominate all other aspects of services trade liberalization.

Dee and Hanslow seemingly offer no explanation for this result in their text other than to say large barriers are involved in the Chinese case. The barriers are indeed large; a little over $250 \%$ as tax equivalent barriers to foreign affiliate capital in the Chinese market. These seemingly come from a strong assumption that barriers to all services in 
China can be represented as tax equivalents (mark ups of price over cost) for banking and telecommunications. They use a Kalirajan et al (2001) study which measures the effects of trade restrictions on the net interest margins of banks, a direct measure of banks mark up of price over cost. They also use Warren's measures of the effects of trade restrictions on the quantities of telecommunications services delivered, converting these to a price impacts using estimates of price elasticities of demand for telecommunication services. Dee and Hanslow's results seemingly follow directly from the very large barrier estimates for China.

Not only is it highly questionable whether barriers in banking and telecommunications reflect barriers generally to service providers in the Chinese market, one can also query whether these barrier measures really make sense. In China, four large state owned banks provide most of the financing to the large state owned enterprise sector and suffer from major non performing loans and make losses. Rate spreads at the margin are high, but foreign entrants to the market lending under similar conditions would also require large spreads. Smaller private banks lending only to the commercial sector have much smaller spreads. At the margin, a 250\% barrier may make no sense. Also, in telecommunications converting quantity impacts to barrier estimates using only demand elasticities (for which estimates are anyway unreliable) and not also supply elasticities is hard to interpret. Everything in the results seemingly follows from barrier estimates, but one is unsure one can believe them. And sellers do not comment on their reliability when discussing model results.

Dee and Hanslow (2000) also find that while service trade liberalization raises overall world income the US and other developed countries can experience welfare losses 
with no explanation provided for this feature of model results. In contrast certain developing countries, and particularly China as noted above, experience large welfare gains (14\% of GDP for China) largely due to the large asymmetry in initial barrier sizes in services across developed and developing countries.

Brown, Deardorff and Stern explicitly modify their earlier analyses to incorporate foreign direct investment flows, and also obtain considerably larger welfare effects from services liberalization, showing that the world as a whole gains while some countries lose. Economies such as Japan and Hong Kong show large gains; the US loses under some specifications gains under others; Canada loses. The larger size of service barriers then goods barriers and their relative size assumed countries seems to be key. They do not seem to report the barrier estimates they use in their text, and neither do Robinson et al.

\subsection{Possible Themes of Results}

Discounting the issue of the reliability of the barrier estimates, these modelling results can be taken as suggesting that a removal of service trade restrictions which implies barriers towards foreign investment flows whose removal attracts capital to countries that had earlier had large barriers towards inward investment flows can yield significant gains, as in China. Barriers to entry for service providers in these markets can also in some cases generate rents part of which accrue to foreign investors; liberalization of services trade can erode these. While there are also terms of trade effects generated by induced FDI flows, as discussed in Brown et al (1996), these also arise in non FDI models. Hence the added feature of factor flow liberalization which mode 3 and 4 GATS 
liberalization facilitates seem to be key to model results. If developing countries are able to use service trade liberalization to attract inward capital flows this suggests considerable gains to them. At the same time unilateral changes in investment regimes, independently of changes in trade barriers in services might achieve much the same result (such as relaxation of equity limits on foreign participation in key sectors). This differentiation between services trade liberalization and unilateral changes in investment barriers may seem somewhat confusing given that most FDI is in the services sector; and that restrictions on FDI (eg screening, equity limits) need to be scheduled as mode 3 restrictions in the relevant GATS sector. But mode 3 GATS liberalization in services is all about changing the conditions for foreign capital to enter the relevant domestic sector.

\subsection{Modeling Mode 4 Restrictions}

This also raises the issue of what might happen were significant liberalization of services under mode 4 supply to allow significant movement of service providers. Some years ago, Hamilton and Whalley (1984) produced a calculation of the potential impacts on the global economy from the elimination of all restrictions on labour mobility. While clearly extreme as a liberalization scenario, they showed that under some conditions worldwide income could more than double and there would be major distributional impacts across countries. Thus, explicitly modelling mode 4 supply services liberalization would seem to be the potential source of even larger effects.

This work on mode 4 is not without its difficulties, in particular because most countries require foreign workers to be paid at the same rates as nationals (thereby undermining the cost advantage of DC suppliers). This is a limitation on the quantitative 
studies showing gains from greater labour mobility. Labour market

restrictions/regulations are equally important (regulation of pay and conditions, recognition of qualifications, etc.). Further mode 4 only covers temporary movement permanent migration is explicitly excluded. GATS technical definitions aside, the economic impact and policy questions are different for temporary and permanent migration.

Winters (2001) provides a later calculation which modifies the Hamilton-Whalley assumption of homogeneous labour across countries, by assuming that when workers move from low to high income countries only one quarter of the productivity difference is returned as a higher wage. Under this modified assumption gains fall to only $\$ 300$ billion/year, but still more than the gains from global liberalization of both goods and factors reported by Dee and Hanslow (2000). Similar sensitivity analyses in which global gains from elimination of migration restrictions are reduced when efficiency differences in labour are assumed across countries were also reported in the original HamiltonWhalley paper.

Winters et al (2002) also indicate that large potential gains would follow from only a small increase in the movement of people between low and high income countries. They suggest that increasing developed country quotas for incoming temporary movement of natural persons (TMNP) by $3 \%$ of the existing labour will generate global income gains of $\$ 150$ billion/year, emphasizing the large benefits that would follow from even modest liberalization of mode 4 GATS restrictions of service provider mobility. Winters (2002) further discusses the economic implications of liberalizing mode 4 restrictions. 
At present lower developing country labour costs show up more in services trade via mode 1 than mode 4 , given that many countries require equal pay for mode 4 entrants compared to nationals. In some sectors, in particular professional and computer services, out-sourcing has been driven by the lower wages of professionals in DCs. Out-sourcing of not only data entry, but increasingly research and other more skilled work, involves service supply via mode 1 and not mode 4 and hence even without mode 4 liberalization significant gains can occur. Out-sourcing effective poorly captured in existing studies.

\subsection{Overview}

So an overview of model themes might be that while all these studies focus on multilateral liberalization of global trade in services rather than unilateral liberalization as discussed earlier, they all seem to point in the same direction in terms of general effects. More precise effects by country differ considerably. They suggest that if services are liberalized with no accompanying liberalization of factor markets, as in goods trade gains are small. If, however, services liberalization becomes a mechanism through which impediments to factor flows (FDI) are removed, then gains are large and uneven across countries. Importantly, it seems that the large effects in these model results need not come from liberalization of service trade, per se, but from the assumed accompanying liberalization of factor markets. This is parallel to work on goods trade, where accompanying liberalization of factor markets internationally also produces sometimes large and uneven effects across countries.

Thus a major role for service trade liberalization may be to serve as surrogate global factor market liberalization by allowing for freer factor flows under modes 3 and 4 
of GATS schedules. While such liberalization may be hard to achieve directly, achieving it indirectly under the name of service trade liberalization may be the source of major gain and also country impact. It may also be the major issue at stake for the developing countries in services negotiations in the WTO. Attracting more capital, and achieving a labour outflow so as to reapportion factor ratios across broad blocs of countries, might be the source of largest global gain and distributional impact across countries from services trade liberalization. 


\section{Econometric Literature on Growth Performance and Services $\underline{\text { Trade Liberalization }}^{4}$}

Recent econometric work by Mattoo, Rathindran, and Subramanian (2001) and Francois and Schuknecht (1999) takes a different approach to assessing the implications of trade liberalization in services and evaluates the links between growth performance and service sector liberalization. This literature is also relevant to any discussion of the impacts of services trade liberalization on developing countries.

\subsection{Early Literature}

Though this work shows a significant and strong relationship between growth performance and openness in key service sectors, discussion of these issues is in fact considerably older. Goldsmith (1969), in a seminal earlier piece, placed heavy stress on the role of financial services in allowing financial investments to flow to their most productive uses, and hence in generating growth of output and income. He suggested that the ratio of the value of financial intermediary assets to GNP was a variable that in some way represented country performance of the financial sector. He used it in a regression in which economic growth rates were the dependent variable, and found what he termed a "rough parallelism" between growth performance and the level of financial development as represented by this variable. This lead to later work all pointing in the same direction as recent work, namely that openness and degree of development of the service sectors is associated with stronger growth performance.

\footnotetext{
${ }^{4}$ See again the discussion of these issues in Copeland (2002).
} 
King and Levine (1993), in later work subsequently controlled for other factors influencing long run growth performance. They used further measures of country development for the financial sector in their growth regressions, including the ratio of liabilities in the financial system to GDP and the ratio of gross claims on the private sector to GDP. They found that these measures played an important role and implied an econometrically significant relationship. They assessed whether the level of country financial sector development in 1960 as measured by one of their ratios predicted the rate of growth for the country over the 1960-1990 period, and found that the level of financial sector development in 1960 was a significant predictor of later period economic growth.

In a later paper Levine (1997) further assessed the role that financial sectors

played in economic development. He evaluated five functions performed by the financial services sector, including facilitating the trading of risk, allocating capital to its most productive uses, monitoring managerial performance, mobilizing savings through financial innovation, and easing the exchange of goods and services.

\section{2 $\quad$ Recent Work}

It is only in more recent work, however, that the role of trade and openness in service sectors and their influence on growth surfaces more explicitly. Francois and Schuknecht (2000) regress growth rates of real per capita GDP on a measure of the degree of openness in trade, key macroeconomic variables, and a measure of concentration in the financial sector. They find a strong relationship between growth rates and financial sector competition, this claim suggesting a positive link between openness and trade. 
Mattoo, Rathindran, and Subramanian (2001) use policy rather than results based measures of openness of country services regimes (in contrast to Francois and Schuknecht). They construct such openness measures for two key service sectors, basic telecoms and financial services and use these in growth regressions. Their econometric evidence shows that openness in service sectors influences long run growth performance. This link is relatively strong in the financial sector and less strong (but nevertheless statistically significant) in the telecommunications sector. Their estimates suggest that with fully globally open telecom and financial service sectors, growth rates in individual economies may be up to 1.5 percentage points higher than for other countries with more closed regimes.

\subsection{Issues of Interpretation}

At first sight this evidence seems striking, pointing to liberalization of service sectors as a route to faster growth and development, and suggesting that trade liberalization in service sectors can also be key for developing countries in achieving enhanced growth performance. There are, however, issues this work raises as with earlier work reviewed here.

One is that this work is generally a theoretical and does not provide solid analytical underpinnings for service trade liberalization and its links to growth performance. Although Francois and Schuknecht emphasize the role of scale economies and cost structures in financial services and the link to market structure, their theory points (as in most theoretical work on trade liberalization) to once and for all level effects rather than permanent growth effects. Thus whether elevated growth from liberalization 
is only a transitional effect, or a more permanent effect of longer standing is the issue.

Indeed, there are parts of the endogenous growth literature (such as Young (1996)) that suggest there are ways in which trade barriers which partly internalize an internalized externalities can raise growth rates and protection can be welfare improving. At first sight, such arguments might well also apply to services. However, also following endogenous growth literature, a key characteristic of services trade - the need for simultaneous production and consumption of the traded service - might imply that services liberalization moves resources from sectors that do not possess these attributes to those that do, and long run growth rates rise.

Also, there are key issues with excluded variables in these analyses. Thus, in discussing financial services liberalization, there is clear evidence that economies with higher savings rates grow more quickly as investible funds are channelled into productive employment. The links between financial structure and development are long discussed, in both McKinnon (1973) and Shaw (1973), for instance. Financial intermediation will thus correspondingly grow with savings as intermediation helps these savings flow from lenders to borrowers. What drives the growth is primarily the higher level of savings and investment, what facilitates the process is the intermediation. Thus opening up financial services sectors to international competition where domestic savings rates are low need not facilitate higher growth, and to attribute higher growth rates to elevated financial intermediation alone can again potentially be misleading.

This econometric evidence, however, has been widely cited as showing a strong link between financial services liberalization and growth performance; and if correct has 
major implications for policy reform in developing countries. The caveats noted above should, however be kept in mind in interpreting results. 


\section{Sectoral Issues: Health and Transportation}

Two key sectors which have attracted attention as possible areas for developing countries to focus on in their services liberalization are health services and transportation. These are briefly discussed here, even though model based analyses do not centre on these.

\subsection{Health Services}

Here, it is often claimed that health services represent an area in which developing countries have the potential to become major exporters; either by attracting foreign patients to domestic hospitals and health care facilities or by sending health workers abroad temporarily. As Mattoo (1999) points out, Cuba provides an example of this. There, government policy is to make Cuba into a world medical leader. A trading company, SERVIMED, was created by the government to offer tourism/health packages. In 1995/96, according to Mattoo, 25,000 patients and 1,500 students went to Cuba for treatment and training generating revenues for Cuba of US \$25 million in the year. Cost savings for both patients and insurers can be very significant. Mattoo suggests that the cost of coronary bypass surgery in India is about $5 \%$ of that in developed countries. The UN and WHO (1998) estimate the cost of liver transplants in India to be about one tenth of that in the United States.

There are many barriers to international trade in health services, not the least of which is portability of health insurance coverage. For instance, US federal or state government employee coverage is limited to certified practitioners in the United States

(or a specified state. The UN and WTO (1998)) estimate that $3 \%$ of the 100 elderly 
living in OECD countries retiring to developing countries would bring revenues of perhaps US \$10-15 billion a year in medical expenses to developing countries. Another barrier is visa and house purchase/registration restrictions in the developing world that potential longer term patients face. Prima facie, the potential benefits to developing countries in this area seem large, but there appears to be few or no quantitative studies.

\section{$\underline{\text { Transport Services }}$}

In the area of transport services, there is a general presumption that no other services category has such a pronounced effect on both the level and pattern of developing county trade. Internal transportation is costly and time consuming, and presents barriers to trade in goods not only in terms of financial cost but also in terms of spoilage and breakage. In ocean shipping, negotiated bilateral freight rates between ports of countries often imply large costs for transshipment between ports of developing countries. Much inter developing country trade can take place via OECD ports (Lagos to Accra via Rotterdam, for instance), and negotiated freight rates partially drive this. (See Zerby and Conlon (1983).)

In addition developing country suppliers of transportation services are restricted in terms of access to developed country service markets. The higher costs of domestic providers can be very substantial, and so the benefits of developing country suppliers gaining access to these markets could be very large. Francois, Acre, Reinert and Flynn (1996) in analyzing the Jones Act in the US which restricts coastal US shipping to US vessels suggests local US suppliers of shipping services are perhaps 300\% more costly than low cost foreign suppliers and compute large gains for the US from such 
liberalization. It follows that large benefits would also accrue to developing country suppliers.

Airline transportation represents another area where developing country gains from improved access could be large due to their lower costs. Exclusionary practices such as cabotage and denied grant of fifth freedom rights exclude them from internal developed country service markets. These issues are discussed in Findlay (1997). Thus as in health services potentially significant gains would accrue to developing countries from genuine multilateral service liberalization. 


\section{Concluding Remarks}

This paper both discusses the potential impacts of services trade liberalization on developing countries and reviews existing quantitative studies. Its purpose is to distill themes from studies rather than to advocate policy change. The picture that emerges is seemingly one of valiant attempts to quantify in the presence of formidable analytical and data problems. The basic intuition seems to be that with genuine two sided (OECD/non OECD) liberalization in services that are seemingly considerably labour intensive, the potential may be there for significant developing country gains. This position is seemingly not endorsed by studies, neither is it contradicted.

One difficulty with existing studies is that the conceptual underpinnings of trade in services and how analytically this trade differs from trade in goods, if at all, needs to be sorted out before impacts on developing countries are discussed. Key here are mobility issues for service providers (both firms and workers), and the functional treatment of individual service items (banking, insurance, telecoms, etc.). Recent analytical work suggests that liberalization in these service items need not always yield gains. The discussion and measurement of barriers to service trade is also problematic. One is talking of domestic regulation, entry barriers, portability of providers, competition policy regimes more so than barriers at national borders as with tariffs. Both representing and quantifying barriers raise major difficulties, and these are spelled out.

As a result, numerical modelling work on the effects of service trade barriers which uses ad valorem equivalent modelling is not fully convincing. In addition, individual country results vary considerably across studies in ways it is hard for outsiders to recognize. Studies do, however, point towards a tentative conclusion that effects are 
small and positive for most countries if FDI flow changes are absent, but much larger and more variable across countries if they are present. This all perhaps suggests that mode 3 GATS liberalization (roughly captured in some studies) could be very important for developing countries; Mode 4 GATS liberalization (not covered) is likely even more important given large barriers to labour flows across countries and recent initial studies clearly point in this direction.

If service trade liberalization is a surrogate for improved functioning of global factor markets in which more capital flows to developing countries and more labour flows from then, developing countries could benefit in a major way. The paper concludes by evaluating recent econometric studies on services liberalization growth linkages, and sectoral issues in health services and transportation. 


\section{8. $\quad \underline{\text { References }}$}

Benjamin, N. and X. Diao (2000), "Liberalizing Services Trade in APEC: A General Equilibrium Analysis with Imperfect Competition.” Pacific Economic Review 5(1). (2000): 49-75.

Bhattarai, Keshab and John Whalley (1998) “The Division and Size of Gains from Liberalization of Service Networks," National Bureau of Economic Research Working Paper: 6712, August 1998.

Brown, D., A. Deardorff, A. Fox and R. Stern (1996), “Computational analysis of goods and services liberalization in the Uruguay Round" in Martin W. and L. Winters eds, The Uruguay Round and the Developing Economies, Discussion Paper No. 307, World Bank, Washington DC, pp. 365-80.

Brown, D., A. Deardorff and R. Stern (2002), "Computational analysis of goods and services liberalization in the Uruguay Round and the Doha Development Round" Discussion Paper No. 489. Research Seminar in International Economics, School of Public Policy, The University of Michigan, 2002. http://www.fordschool.umich.edu/rsie/workingpapers/Papers476-500/r489.pdf

Chadha, Rajesh (2000) "GATS and the Developing Countries: A Case Study of India," in Robert M. Stern, (ed.) Services in the International Economy, University of Michigan Press, 2000.

Chadha, R., D. Brown, A. Deardorff and R. Stern (2000), "Computational Analysis of the Impact on India of the Uruguay Round and the Forthcoming WTO Trade negotiations," Discussion Paper No. 459, School of Public Policy, University of Michigan, 2000. 
Chen, Zhiqi and Lawrence Schembri (2002) "Measuring the Barriers to Trade in Services: Literature and Methodologies" in Curtis, J. M. and D. C. Ciuriak, eds. Trade Policy Research 2002. Department of Foreign Affairs and International Trade, Canada 2002.

Chia, Ngee Choon and John Whalley (1997) “A Numerical Example Showing Globally Welfare-Worsening Liberalization of International Trade in Banking Services,” Journal of Policy Modelling, April 1997; 19(2): 119-27.

Copeland, Brian (2002) "Benefits and costs of trade and investment liberalization in services: Implications from trade theory" in Curtis, J. M. and D. C. Ciuriak, eds. Trade Policy Research 2002. Department of Foreign Affairs and International Trade, Canada 2002.

Dee, P. and K. Hanslow (2000), "Multilateral Liberalization of Services Trade," Productivity Commission Staff Research Paper, Ausinfo, Canberra.

Findlay, Christopher (1997), “The APEC Air Transport Schedule” Pacific Economic Papers No.273 November 1997 Australia-Japan Research Center ANU.

Findlay C. and T. Warren, eds, (2001) Impediments to Trade in Services: Measurement and Policy Implications, New York: Routledge.

Fink, C. and A. Mattoo and I. C. Neagu (2001) "Trade in International Maritime Services: How Much Does Policy Matter?” World Bank wp.2522, http://econ.worldbank.org/files/1338_wps2522.pdf

Francois, J., B. McDonald and H. Nordstrom (1994), “The Uruguay Round: A Global General Equilibrium Assessment" Centre for Economic Policy Research, Discussion Paper: 1067 November 1994; 44 
Francois, J. and L. Schuknecht (1999) "Trade in Financial Services: Precompetitive Effects and Growth Performance,” CEPR Discussion paper 2144, May 1999.

Francois, J. and L. Schuknecht (2000) "International Trade in Financial Services, Competition, and Growth Performance," Centre for International Economic Studies, No. 6.

Francoise, J., and B. Hoekman (1999), "Market Access in the Service Sectors", Tinbergen Institute, manuscript, 1999.

Francois J., H. Acre, K. Reinert and J. Flynn (1996), “Commercial Policy and the Domestic Carrying Trade" The Canadian Journal of Economics, Vol. 29, No. 1. (Feb., 1996), pp. 181-198.

Goldsmith, Raymond W., (1969), "Financial Structure and Development”, Yale University Press, New Haven, 1969.

Hamilton, B. and J. Whalley (1984) "Efficiency and Distributional Implications of Global Restrictions on Labour Mobility: Calculations and Policy Implications” Journal of Development Economics, 14(1-2) January-February 1984, pp. 61-75.

Hardin, A., and L. Holmes (1997), "Services Trade and Foreign Direct Investment", Staff Research Paper, Industry Commission. Canberra: Australian Government Publishing Services.

Hoekman, B. (1995) “Assessing the General Agreement on Trade in Services," in W. Martin and L.A. Winters (eds), The Uruguay Round and the Developing Economies, Discussion Paper No. 307, World Bank, Washington DC, pp. 327-64. Kalirajan, Kaleeswaran (2000), "Restrictions on Trade in Distribution Services," Productivity Commission Staff Research Paper, Ausinfo, Canberra. 
Kalirajan, K., G. McGuire, D. Nguyen-Hong and M. Schuele (2001), "The price impact of restrictions on banking services", in Findlay C. and T. Warren, eds, Impediments to Trade in Services: Measurement and Policy Implications, New York: Routledge.

Kang (2001), “Trade in Education Services and the Impacts of Barriers to Trade," in

Findlay C. and T. Warren, eds, Impediments to Trade in Services: Measurement and Policy Implications, New York: Routledge.

Kemp, S (2001), “Trade in Education Services and the Impacts of Barriers to Trade," in Findlay C. and T. Warren, eds, Impediments to Trade in Services: Measurement and Policy Implications, New York: Routledge.

King, R. G. and R. Levine (1993), “Finance, Entrepreneurship and Growth: Theory and Evidence," Journal of Monetary Economics, XXXII (1993).

Levine, Ross (1997), "Financial Development and Economic Growth: Views and Agenda", Journal of Economic Literature, June 1997.

Markusen, J. and T. Rutherford (2002), "Developing domestiv entrepreneurship and growth through imported expertise," CEBR Discussion paper NO. 2002-12.

Markusen, J., T. Rutherford and D. Tarr (2000), “Foreign Direct Investment in Services and the Domestic Market for Expertise,” Policy Research Paper No. 2413, World Bank, Washington D.C. August.

Mattoo, Aaditya (1999), “Financial Services and the WTO: Liberalization Commitments of the Developing and Transition Economies", Policy Research Working Paper No. 2184, Developing Research Group, World Bank, September 1999. 
Mattoo, A., R. Rathindran and A. Subramanian (2001) "Measuring Services Trade Liberalization and its Impact on Trade Growth: An Illustration," World Bank Working Paper 2655.

McGuire, G. and M. Schuele (2001a), "Restrictiveness of International Trade in Banking Services", in Findlay C. and T. Warren, eds, Impediments to Trade in Services: Measurement and Policy Implications, New York: Routledge.

McGuire, G., M. Schuele (2001b) and T. Smith, "Restrictiveness of International Trade in Maritime Services", in Findlay C. and T. Warren, eds, Impediments to Trade in Services: Measurement and Policy Implications, New York: Routledge.

McKinnon, Ronald (1973) Money and Capital in Economic Development. Washington D.C., Brookings.

Melvin, James R. (1989) "Trade in Producer Services: A Heckscher-Ohlin Approach," Journal of Political Economy, October 1989, 97(5): 1180-96.

Nguyen-Hong, D. (2000), "Restrictions on Trade in Professional Services", Productivity Commission Staff Research Paper, Ausinfo, Canberra.

Reinert, K. and J. Francois 1997 Applied methods for trade policy analysis: A handbook. Cambridge; New York and Melbourne: Cambridge University Press, 1997; xv, 560.

Robinson, S., Z. Wang and W. Martin (1999) “Capturing the Implications of Services Trade Liberalization," Invited Paper at the Second Annual Conference on Global Economic Analysis, Ebberuk, Denmark, June 20-22.

Ryan, C. (1990) “Trade Liberalization and Financial Services,” The World Economy, pp. 349-366. 
Ryan, C. (1992) "The Integration of Financial Services and Economic Welfare” in A. L. Winters ed, Trade flows and trade policy after 1992. Cambridge; New York, Melbourne: Cambridge University Press, 1992; 92-118

Shaw, Edward S. (1973), Financial Deepening in Economic Development, New York: Oxford University Press.

Shoven, J. and J. Whalley (1984) “Applied General Equilibrium Models of Taxation and International Trade: An Introduction and Survey" Journal of Economic Literature, 22(3) September 1984, pp. 1007-51.

Trewin, Ray (2001) “A Price-Impact Measure of Impediments to Trade in Telecommunications Services," in Findlay C. and T. Warren, eds, Impediments to Trade in Services: Measurement and Policy Implications, New York: Routledge. United Nations and WHO (1998), "International Trade in Health Services - A Development Perspective," in S. Zarrilli and C. Kinnon, eds, United Nations Conference on Trade and Development (Geneva).

UNCTAD MAST 2.1 (2002)"Measures Affecting Trade in Services (MAST) Database Version 2.1" UNCTAD.

Verikios, G. and X. Zhang (2000) "Sectoral impact of liberalising trade in services," paper presented to the Third Conference on Global Economic Analysis, Melbourne, June 27-30, http://www.monash.edu.au/policy/conf/53Verikios.pdf Warren, Tony (2001a), "The identification of impediments to trade and investment in telecommunications services," in Findlay C. and T. Warren, eds, Impediments to Trade in Services: Measurement and Policy Implications, New York: Routledge. 
Warren, Tony (2001b), “The impact on output of impediments to trade and investment in telecommunications services," in Findlay C. and T. Warren, eds, Impediments to Trade in Services: Measurement and Policy Implications, New York: Routledge.

Winters, L. Alan (2001), “Assessing the Efficiency Gain for Further Liberalization: A Coment" in Sauve, P. and A. Subramanian, eds, Efficiency, Equity and Legitimacy: The Multilateral Trading System at the Millennium, Chicago University Press, Chicago, 2001.

Winters, L. Alan (2002), "The Economic Implications of Liberalizing Mode 4 Trade", Joint WTO-World Bank Symposium on 'The Movement of Natural Persons (Mode 4) under the GATS', WTO, Geneva, 11-12 April, 2002.

Winters, A., T. Walmsley, Z.H. Wang and R. Grunberg (2002), "Negotiating the Liberalization of the Temporary Movement of Natural Persons", Discussion paper 87, University of Sussex, October 2002.

Whalley, John (1985) Trade Liberalization Among Major World Trading Areas. Cambridge Mass: MIT Press, 1985.

Whalley, John (2000) "What can the Developing Countries Infer from the Uruguay Round Models for Future Negotiations" Policy Issues in International Trade and Commodities, Study Series No.4, UNCTAD, New York and Geneva, 2000.

Young, Alwyn (1996) "Invention and Bounded Learning by Doing," in Grossman, Gene M. (ed), Economic growth: Theory and evidence, Volume 1, Elgar Reference Collection, International Library of Critical Writings in Economics, No. 68, Cheltenham, UK: Elgar, distributed by Ashgate, Brookfield, VT, 1996, pp. 50635. Previously published: 1993. 
Zerby, J., and R. Conlon (1983) "Joint Costs and Intra-Tariff Cross-Subsidies: The Case of Liner Shipping.” Journal of Industrial Economics, June 1983, 383-96. 